\title{
On the Accuracy of Latin American Trade Statistics: a Nonparametric Test for $1925^{*}$
}

\author{
M. d. Mar RUBIO \\ mar.rubio@upf.edu \\ Department of Economics and Business, Universitat Pompeu Fabra, Carrer Ramon Trias Fargas, 25 -08005 Barcelona (Spain) \\ tel: +34 935422674 fax: +34 935421746 \\ and \\ Mauricio FOLCHI \\ maurcio.folchi@upf.edu \\ Universitat Pompeu Fabra and Universidad de Chile, Carrer Ramon Trias Fargas, 25 -08005 Barcelona (Spain)
}

\begin{abstract}
This paper proposes a nonparametric test in order to establish the level of accuracy of the foreign trade statistics of 17 Latin American countries when contrasted with the trade statistics of the main partners in 1925. The Wilcoxon Matched-Pairs Ranks test is used to determine whether the differences between the data registered by exporters and importers are meaningful, and if so, whether the differences are systematic in any direction. The paper tests for the reliability of the data registered for two homogeneous products, petroleum and coal, both in volume and value. The conclusion of the several exercises performed is that we cannot accept the existence of statistically significant differences between the data provided by the exporters and the registered by the importing countries in most cases. The qualitative historiography of Latin American describes its foreign trade statistics as mostly unusable. Our quantitative results contest this view.
\end{abstract}

JEL codes: N73, F14, C14,

Keywords: Latin America, statistical accuracy, international trade data, nonparametric methods, petroleum trade, coal trade.

\footnotetext{
- This paper is the result of research at an early stage of a project entitled 'Imports and economic modernization in Latin America 1890-1960', which is financed by the Spanish Ministry of Education (Project No: BEC2003-00190 MCYT). We are obliged to the rest of the team members for their encouragement and help: A.Carreras, X.Tafunell, C.Yañez and A.Hofman. The authors gratefully acknowledge the research assistantship of F. Notten. The usual disclaimers apply.

Corresponding author: mar.rubio@upf.edu
} 


\section{INTRODUCTION}

The issue of the (in)accuracy of the foreign trade statistics remains in the economics, development and trade literature to the present day (Parniczky (1980); Rozansky and Yeats (1994); Makhoul and Otterstrom (1998) ). This paper proposes a nonparametric test in order to establish the level of accuracy of the Latin American foreign trade statistics when contrasted with the trade statistics of the main trading partners.

The study of Federico and Tena (1991) showed that, in historical terms, the accuracy of foreign trade statistics seems to be more robust than previously thought. The results of this paper also point in such direction. Nevertheless, this paper departs from previous exercises regarding the (in)accuracy of foreign trade data in several aspects. First, the paper focuses in the trade of a particular region in a single year. That is the paper provides a test for the accuracy of the foreign trade statistics of 17 Latin American countries for the year 1925. Second, rather than testing for the accuracy of the overall trade figures, the test is performed on data registered for a couple of quite homogeneous products, petroleum products and mineral coal. Third, the test applies to the accuracy of both the volumes and values registered on the official statistics of the exporting and importing countries. Most previous exercises did only test for the accuracy of the values registered, since the aggregate trade figures were used. Most of the previous tests tended to compare figures provided international bodies (OECD, IMF, League of Nations, etc), whereas here the foundations of such figures, the official statistics of the individual countries, are contrasted. Fourth, the Wilcoxon Matched-Pairs Signed-Ranks test is used to determine whether the differences between the data registered by exporters and importers are meaningful, and if so, whether the differences are systematic in any direction. At the end of the day, the question addressed is whether the differences observed are statistically meaningful. In other words, whether the story told from the exporters' side is or it is not 
substantially different from the story told using the importers' figures. The paper, therefore, is not concerned with the issues of why and where from do the differences arise, these are important questions on their own right, but exceed the aim of this paper.

The first section of the paper presents the problem and specifies the issues to be investigated. The second section contemplates the nature of the data proposed for the test and introduces the data set to be used. Section three offers some preliminary contrasts of the data offered by exporters and importers. In section four the choice of a nonparametric test is justified and the workings of the test are revealed. Section five summarizes the results obtained. The conclusions recapitulate the main findings and propose a research agenda.

\section{THE PROBLEM}

The general mistrust placed on trade statistics, particularly those of underdeveloped countries, represents a heavy burden on economic history research, since trade statistics are one of the oldest and most complete economic series available for analysis. For instance, a research project such as the described in Carreras et al. (2003) or Carreras et al. (2004) aimed at estimating the level of economic modernization in Latin American and Caribbean countries before World War II making systematic use of the trade statistics of these countries as well as of their principal trading partners in the developed world is immediately under suspicion.

From the seminal work of Morgernstern (1963) to the present day, the users of trade figures are aware of the divergence that exists between exporters' and importers' figures. The impression from the economic literature is that the researcher should be even more suspicious of the data the more underdeveloped the country. Among others, the studies of Naya and Morgan (1969), Yeats (1990), Rozansky and Yeats (1994) and, Makhoul and 
Otterstrom (1998), show that the accuracy of trade statistics provided by developed countries is higher than that of the developing countries. For instance, Makhoul and Otterstrom (1998) found that the quality of the OECD trade statistics is much better than that provided by the non-OECD in a relatively recent period such as 1980 to 1994 . Also Rozansky and Yeats (1994 ) found that discrepancies between importers' and exporters' reports appear especially important for the less developed countries.

That underdeveloped countries shall misreport statistics more often than developed nations comes as no much of a surprise. Allegedly many of the causes for misreporting have to do with lack of means for the collection of data, systematic distorted statistics for a specific purpose --improve credit worthiness; collect (or avoid) higher taxes--, simple corruption, smuggle, etc., all of which seem to occur more often in low income countries (see Yeats (1990)). Following such a line of reasoning the straightforward solution seemed to be to use the statistics of the more developed trade partners instead, which are expected to be of higher quality. However, Yeats (1995) concluded that 'the partner country gap filling procedures have little or no potential for improving the general coverage or quality of international trade data'. His final remark points at the need of 'improved procedures for data collection and reporting at the country level'.

In fact, there are a wide array of potential matters that would need to improve in order to reduce the differences between the quantities and, overall the values, annotated at the port of origin and that registered at destination: different accounting methods (CIF versus FOB, general versus special trade), different time of recording (goods movement versus money movement, fiscal versus calendar years), prices used (declared prices versus official prices), different units of measurement (currencies and exchange rates; units, dozens, weight, volume, length, etc), misclassification of products (thousand subcategories versus 'all others' type of categories), geographical misallocation (country of consignment 
versus country of origin/destination), just to name the most relevant. A detailed explanation these and more reasons for discrepancies can be found in Allen and Ely (1953) and also Federico and Tena (1991). Given the list of issues, the ample pessimism about the accuracy and usefulness of international trade statistics for economic analytical purposes is comprehensible.

In historical terms, the view of Don (1968) that the 'comparison of trade statistics, for a historical analysis of economic relations between two countries, must be abandoned', and the cautions of Platt (1971) regarding the interpretation of the Latin American trade statistics before World War I, added to the overall wariness. Also McGreevey (1975) insisted in such direction when indicating that the trade data of industrialized countries may offer supplementary and alternative sources, especially for the Latin American countries, which only have incomplete and inexact commercial records.

Few exercises, however, challenge the general distrust on trade statistics. The work of Federico and Tena (1991) contested some of the above issues using international foreign trade statistics of the pre-World War II period and focusing on overcoming errors due to geographical assignment. Their results strengthened the trust on the accuracy of foreign trade statistics, at least at the aggregate level. In addition, they found no significant relationship between the level of development of the countries and the quality of the trade statistics produced.

Given the state of the art, any research based upon Latin American trade statistics first need to face the challenge of proving that useful and trustworthy interpretations can be extracted from the historical trade figures. This is the challenge of the present paper. Economic historians cannot hope for improvement of data collected many years ago, but renouncing to use trade statistics altogether is, to the say the least, inappropriate. The problems associated to trade statistics must be recognized, but also the magnitude of the 
discrepancies observed must be placed within context. For some purposes a difference that in some metric looks large might in another metric be unimportant. How large is large in the present case depends, as usual, on the question asked. Differences that at the country level may look abysmal, placed in the context of the region will be a minor problem for the analysis at hand. The remaining of the paper is aimed at proving that the story told from the exporter side is almost identical to the story told using the importers' figures when analyzing the Latin American countries within the context of the region. The question addressed is whether the differences observed are statistically (and economically) meaningful for the interpretation of the imports of petroleum and coal of the Latin American countries relative to each other.

\section{THE DATA}

Before having a look at the data, lets reflect about the nature of the data proposed for the test. It has been already said that rather than testing for the accuracy of the overall trade figures, the paper concentrates on the reliability of the data registered for a couple of quite homogeneous products, petroleum products and mineral coal. There are some reasons to believe that specific product comparisons may be more fruitful than overall trade contrasts. To start with, contrast of homogeneous products had proven to yield better results. As referred by Federico and Tena (1991), the analysis of homogeneous commodities, such as wheat, provides a much less pessimistic view of the quality of the data (see the results of Ricci (1914)). Indeed, homogeneous products have some advantages at the time of contrasting figures at port of origin and that of destination. Homogeneous implies simpler standardization and classification. Fewer errors can be attributable to misclassification of products and measurement error. Even when petroleum and coal products were not totally free of such problems the truth is that still the most 'detailed' listings did not go beyond three categories for coal and up to a dozen for 
petroleum products in 1925. The units of measurement although not completely standardized —long tones, short tones, kilograms, barrels, gallons, litters, cubic meters, were all in use- were straightforward to translate into common units (metric tones). In addition, the nature of the products made them difficult to smuggle in sizeable amounts. Finally, there was little incentive to systematically distort the figures in order to avoid taxes. Duties on imports of fossil fuels were small, if any, in the 1920s, according to the report by the U.S. Department of Commerce (by J.R.Bradley) (1931). As for export taxes, although existed, they were affordable compared to the additional set of taxes paid at origin (production taxes, royalties, handling taxes, etc).

Homogeneity and the nature of the products chosen gets rid of some of the problems listed in the previous section, especially when contrasting quantities rather than values traded. Yet some important ones remain on the list. It is the case of the geographical misallocation of trade. Where the final destination was taken to be the port of landing, the trade to all non-seaboard countries (Bolivia and Paraguay) would had been misallocated in the exporters' reports as corresponding to the intermediate countries (Argentina, Chile, Uruguay and Peru). The importance and possible ways of correcting this effect is investigated in Carreras-Marín and Badía-Miró (2005, forthcoming). Another issue, relevant only to the selected products, is the treatment given to bunkering. In some instances coal and petroleum arriving at Latin American ports would be right away loaded as fuel to departing ships. Some countries may record both the import and the export of such amounts, some other countries may record the importation but not the re-export, finally some other countries may not account at all the amounts unloaded and loaded at port for bunkering purposes. Regardless of the treatment given at the port of destination, the amounts were in all instances recorded at the port of origin as exports to the Latin American country. 
More crucial to the differences between the values reported by the exporters and that reported by the importers is the so-called 'freight factor'. The 'freight factor' is the ratio between the CIF value of a commodity and the freight rate paid for its carriage, and can be taken as a proxy for the difference between CIF and FOB values. According to Moneta (1959), two main rules apply to the freight factor: (1) commodities of low unit value are relatively more expensive to ship than high-value ones and (2) the longer the distance a given commodity is shipped, the higher the freight rate and the higher the freight factor to be applied. Bulky commodities such as coal, petroleum, wheat, cement etc, are included in the first rule, they have a low unit value and are relatively expensive to ship. A telling illustration of the magnitude of the freight factor for bulky commodities is the method used by GATT still in the 1950s according to which the frequent procedure to adjust values from CIF to FOB was to reduce the value of fuel imports by 50 per cent and that of all other imports by 10 per cent (see Moneta (1959)). So in principle, imports of petroleum and coal by Latin America are the worse case scenario for contrasting the values traded according to importers and exporters since both rules apply. The large magnitude of the freight factor should make the values much larger at the port of destination than at port of origin, thus very different.

Having reflected on the nature of the products let's look into the dataset. By 1925, most Latin American countries were net importers of coal and petroleum products, mostly from the United Kingdom, the United States and, Germany; Mexico and Peru also supplied petroleum within the region. According to Rubio and Folchi (may,2005), the United States supplied little more than half of the oil and derivatives imported by the Latin American countries in 1925. Mexico, with a share of 40 per cent of the tonnage, and Peru, with seven percent, together supplied the remaining half. In the case of coal, the United Kingdom was the main supplier of the larger consumers --Argentina, Brazil and Uruguay-- 
while the United States was the chief supplier, sometimes even the only one, of coal to Central America and the Caribbean. In total, the United Kingdom supplied 68 per cent of the coal, the United States 26 per cent, while Germany and Belgium had much smaller shares (3.4 and 0.05 respectively). Altogether the G4 -United Kingdom, United States, Germany and Belgium-- provided 98 percent of the coal imported by the Latin American countries in 1925.

Of the 33 countries that constitute Latin America and the Caribbean at the dawn of the $21^{\text {st }}$ century 18 elaborated trade statistics in 1925 , although only 15 offer sufficient detail about the country of origin of the merchandise and the type of products imported. ${ }^{1}$ These were Argentina, Bolivia, Brazil, Colombia, Costa Rica, Cuba, Chile, Dominican Republic, Ecuador, El Salvador, Guatemala, Haiti, Mexico, Nicaragua and, Peru. Apparently most of the smaller Caribbean islands, neither Honduras nor Panama elaborated trade statistics in 1925. Paraguay did, but the level of detail made them unusable. From the statistics of Venezuela and Uruguay it was not easy to detect the country of origin of the products but the total amounts imported were collected. According to the Société des Nations (1928) most Latin American republics used the Anglo-Saxon system for reporting their imports, that is, they reported 'general trade'. ${ }^{2}$ The same source also informs that only Argentina, Guatemala, Paraguay and, Uruguay used official prices in the valuation of their imports; the rest applied the declared prices. From the exporters' side the official national trade statistics of the United States, the United Kingdom, Germany and Belgium (referred as G4 hereunder) were used, plus the export statistics of Mexico and Peru in the case of petroleum products. The problems of classification of

\footnotetext{
${ }^{1}$ Sources are quoted in the references under the heading 'official publications'.

${ }^{2}$ General trade accrued imports for home consumption plus the imports deposited in entrepôts, generally excluding trans-shipment trade and trade in transit. European countries tended to use the 'Continental system' and reported 'special trade' instead, which only includes the imports for domestic consumption. The few Latin American countries using the continental system were: Argentina, Bolivia, Chile, Paraguay and Peru. See Société des Nations (1928).
} 
products and unification of the different units of measurement (volume in some cases, weight in others) were dealt with using the homogeneous criteria described in Folchi and Rubio (2004). Currencies were unified to the US dollar using the exchange rates in U.S. Department of Commerce $(1925,1926)$. The result was a list of pairs of data, in volume and value, consisting of the figures of trade of petroleum products and mineral coal registered both at port of origin and at port of destination. Table 1 provides the pairs of data for the main trading partners of petroleum with the Latin American countries, while Table 2 does for coal.

\{TABLE 1: Pairs of data, petroleum products\}

\{ TABLE 2: Pairs of data, coal \}

Some issues must be clarified before any further examination of the data. It is possible to understand Tables 1 and 2 as before and after observations of the same shipment. Theoretically, what the tables report are cargoes to a specific destination measured at port of origin and the same cargo measured again when it reached its destination. In practice, the measures correspond to different sources, that is the official publications of the country of origin of the shipment (the amounts exported) and that of the country of destination (the amount imported). From the section above it is clear that the two measures are subject to sufficient hazards to make them differ from each other. Furthermore, exporters (especially the United Kingdom and Germany) did not report minor quantities sold to smallish countries, but these amounts show up in the Latin American home statistics. These cases, where the source was checked but no trade was reported, are represented in Tables 1 and 2 with ceros. It may also be the case that amounts reported in the exporter trade statistics could not be verified at destination for lack of sufficient detail in the Latin American country, or mere inexistence of the source. These cases, where the source was unavailable, are represented in Tables 1 and 2 with a dot. 


\section{SOME PRELIMINARY CONTRASTS}

The first impression from Tables 1 and 2 is somehow hazy. Take the quantities traded first. In the case of petroleum products there are quite few remarkable matches: Brazil, Cuba, Chile, Haiti, Mexico and Peru report tonnages arriving from the United States that are pretty close to the amounts the United States reported as exported to such destinations; Argentina, Bolivia, Costa Rica, Ecuador and Nicaragua reported imports from Peru only kilos away from the Peruvian exports record. But then, on the contrary, less than half of tones reported as leaving the United States to destinations such as Colombia, Costa Rica or Ecuador were reported as imports in such countries, while Guatemala and Salvador declare receiving several times over the amount of oil that departed from the United States. Consider now the case of the quantities of coal imported from G4 shown in Table 2. The contrast of the volume imported according to both types of sources reveals that for a first group of countries a very close match: Argentina, Brazil, Colombia, Cuba, Ecuador, Nicaragua and, Dominican Republic. A second group of countries (Chile, Salvador and Peru) exhibits a less satisfactory correspondence, but still plausible. Finally, four countries show what appear to be irreconcilable differences between their statistics and the reported by the exporting countries. These are Bolivia, Costa Rica, Haiti and Mexico. Turning the attention to the values in dollars in Tables 1 and 2 does not improve the matters. There are observable differences of millions of dollars in Argentina and Brazil over the value reported at the ports of origin of the petroleum or coal such the United States, the United Kingdom, Mexico or Peru. A priori these differences could be thought to correspond to the 'freight factor'. Yet a closer look reveals thousands of dollars under valuations found in the same Latin American countries in the trade with Germany and Belgium. Furthermore, Chile and Cuba report values for millions of dollars below the value assigned at the ports of departure. For all the reasons already 
described differences were expected to be greater in the values than in the quantities, but the sings are not the expected ones in all occasions. Besides, there are countries where the match comes down to few hundred dollars in transactions involving several thousands, as it is the case of the United States coal trade with Nicaragua or Ecuador. It is not clear to the naked eye in which cases the quantities and values reported by importers and exporters are close enough to each other's or just the opposite.

Of course, several measures might be deployed to quantify the error. One measure commonly used is the difference between the sources as percentage of either source, although it implies an arbitrary choice of the source that is to serve as denominator. An alternative practical indicator for the measurement of errors in data that are reported in two sources is shown in the last two columns of Tables 1 and 2. It is the implicit minimal measurement error, IMME, defined by van Bergeijk (1995), which here takes the form: $\{($ destination source - origin source $) /($ destination source + origin source $) * 100\}$. The IMME-indicator assumes implicitly that both sources are wrong, and offers a conservative estimate (indeed a lower limit only) for the measurement error in the data. It should be considered as an optimistic indicator of accuracy. Even with its help it is difficult to take an informed position over the accuracy of the data as a whole. The indicator ranges from 0 to 100 per cent, and takes both positive and negative sings.

Moreover, it is impossible to find out from this indicator whether the 100 per cent found between say the British exports of coal to Costa Rica is more, less or as relevant as the 78 per cent found for Bolivia in the same trade, or the 30 per cent corresponding to Haiti in its coal trade with the United States. All it responds to is to the fact that there are at least 320 tones, 4049 tones and 72 tones respectively misreported in each of these transactions. Even within the same country it is not clear why the 51 percent indicator obtained for the value of the petroleum trade from Mexico to Argentina is better or worse 
than the indicator obtained for the petroleum trade from the United Kingdom (which obtained a minus 69 percent), when there were 9 million dollars in excess in the trade with Mexico and not even a quarter of a million mismatch in the trade with the British. Beyond informing of the existence of country-pairs differences, the simple contrast of individual country data does not help much to determine how important the discrepancies are for acquiring an accurate impression of the coal and petroleum trade in Latin America by 1925.

Federico and Tena (1991) argued that a better test for the reliability is the comparison between the total of each country's trade (according to its own statistics) and the sum of these flows as registered by its partner countries' statistics. That is rather than using country-pairs contrast, they advocate for comparisons of total trade flows. The trade flows from main trade partners of each country’s trade (according to its own statistics) and the sum of these flows as registered by the main partner countries' statistics are reported in Table 3 for petroleum and Table 4 for mineral coal. Only the countries where sources could be checked at both ends are included in these tables.

\{TABLE 3: Trade flows from principal partners, petroleum\}

\{TABLE 4: Trade flows from principal partners, coal \}

Indeed, as prognosticated the comparability of the data improves when the aggregated flows are used instead than the bilateral trade. The range of the IMME indicator improves, since the ceros are not present in the aggregate trade flows, thus it gets rid of the automatic 100 percent indicators. Nevertheless the variation still goes from cero percent, as in the case of the value of the Mexican petroleum imports, to 47 percent (negative) in the quantity of oil traded by Colombia (which in fact respond to Colombia reporting over 5000 tones of oil coming from Costa Rica, oil that was almost certainly from the United States and so reported at origin, but not accounted here on the Colombian 
side). In general the gaps are smaller in quantities than in values, but no general rule applies. Only two sings remain negative in the value of coal traded but in petroleum trade five countries report smaller values than the aggregated values at port of origin. But still at the aggregated level there are many millions of dollars over and underreported at destination. Argentina declared values are almost double of the values for oil at port of origin, while Cuba and Chile report lower values than their exporter partners.

This repeated issue gives ground to question one of the main assumptions of the literature: the exporters report values FOB, the importers report them CIF. In fact, while the former seems to be generally true, the later was not in the 1920s. According to the Société des Nations (1928), more than half of the 17 countries included in Tables 3 and 4, plus the United States, valued and reported their import figures FOB, at least in the period 1913 to 1926. The list includes Cuba, Chile, Guatemala (if imported by sea although added an arbitrary 25 to the value), Honduras, Mexico, Nicaragua, Peru (which added a 20 percent to the value), Dominican Republic and Venezuela. This fact together with the inclusion or exclusion of duties and taxes from the values reported at either end may help to explain the unexpected undervalues at port of destination and that the differences between importers and exporters values were in most cases smaller than the 50 percent rule generally applied for fuels.

Nevertheless, the most striking feature of Tables 3 and 4 is the accuracy of the aggregated figures for the region as a whole. The IMME-indicator obtained for the total tonnage comes down to 1 percent (negative) in the case of petroleum, and 0,2 percent in the case of coal. In absolute terms the implication is that of the over 4 million tones of petroleum and over 6 million tones of coal revealed by the exporters as sold to Latin American countries just over fifty thousand tones of petroleum and thirty thousand of coal got misreported somehow. The aggregate values for the region are not so exciting, for the 
IMME-indicators remain at 11 percent for petroleum and 23 per cent for coal. In absolute terms the implication is that the Latin American countries reported a total value over 20 million dollars above the values the exporters declared they obtained from their sales to Latin America of each of these products. Most of the difference was solely explained by the Argentinean overvaluation in all cases.

If the analysis were brought to an end at this point, the conclusions could only be pessimistic at the country level. The differences seem irreconcilable for some countries. Whichever of the ample list of reasons of the previous section could be blamed for the discrepancies observed. At the aggregate level, however, the results of Federico and Tena still hold, but someone could argue it could be due to mere chance or self-cancellation of errors. Yet as van Bergeijk (1995) remind us 'absolute precision obviously is impossible to achieve and the improvement of the accuracy of economic measurement is in many cases not an optimal solution'. The important question is whether these gaps are sufficient to invalidate any inference extracted from this data. The economic historian would like to be able to take home some lessons from these data that withstand the mistrust on the original data sources. The trust placed on the answer depends very much of the question asked to the data. If the question addressed was about the precise quantity of coal imported by Guatemala, the over 3000 thousand tones discrepancy between the importer and the exporters' sources may be a problem (in per capita terms the difference comes down to $0.11 \mathrm{~kg}$ per capita versus $1.5 \mathrm{~kg}$, see Rubio and Folchi (may,2005)). If the question, however, referred to the imports of Guatemala relative to the rest of the continent, the difference between sources may be trivial: Guatemala imported very little coal relative to most countries of the region whatever source used.

\{FIGURE 1: Total petroleum trade flows, exporter vs importers data\}

\{FIGURE 2: Total petroleum trade flows, exporter vs importers data\} 
In fact, the story told from the exporter's side seems to be very similar to the story told using the importers' figures when analyzing the Latin American countries within the context of the region. Better than the naked eye or the IMME-indicator this can be grasped graphically. If the importers and exporters were issuing exactly the same reports on the quantities and values traded, when plotted against each others a perfect 45-degree diagonal will appear. Figures 1 and Figure 2 present the scatter plot of the data in Tables 3 and 4. The $x$-axis shows the exporter data in logs while the y-axis reflects the importer data also in a log scale. A data point below (above) the straight line indicates that the importer was under-reporting (over-reporting) trade with respect the partner's data. The quantities and values match quite nicely the diagonal line, which links identical values in both axes. From either source Argentina is the country making the larger expenditure in buying energy inputs. From either source Brazil and Cuba were next, though Uruguay spent just much as the latter in buying coal. Do not matter the sources used, Argentina bought more tones of coal than any other Latin American country, followed by Brazil, Cuba, Uruguay, Chile and Mexico. In the case of oil, Cuba bought more tones than any other country, followed by Chile, Argentina, Brazil, Mexico and Uruguay, regardless of whether the exporters or the Latin American nations give the answer. At the other end, Haiti used fewer tones of petroleum and coal than any of its neighbors. Bolivia, even admitting than the exporters could not see her as final destination, thus Bolivian statistics reported more tones than her trade partners, still remain at the bottom buying little coal and petroleum, and so on and so forth. This is not a complete picture of the energy intakes of the region -alternative suppliers and domestic production must be taken into account as in Rubio and Folchi (may,2005))-- but it is a good indication that useful and trustworthy interpretations can be extracted from the historical trade figures of Latin America. However, the graphical representation is still subject to the observer's interpretation, finding some statistical 
reassurance confirming that the stories told from either side are sufficiently similar would strengthen the results.

\section{A NON PARAMETRIC TEST}

It has been already mentioned that is possible to think about the data presented as before and after observations of the same shipment. Theoretically, what the data report are cargoes to a specific destination measured at port of origin and the same cargo measured again when it reached its destination. Before/after matched-pairs tests are widely used in medical, biological, behavioral and engineering experiments, where a choice is to be made between parametric or nonparametric tests of paired data (see, for instance, Bland (1995) and Motulsky (1995)). Paired data means that the values in the two groups being compared are linked, that is both samples have some factor in common, it does not matter whether it is geographical location or before/after treatment. That is why they are also known as 'tests for correlated samples'. In studies that gather before and after measurements like this, interest focuses on the difference between each pair.

The choice between a parametric and a nonparametric test derives from the underlying assumptions about the data to be tested. Two assumptions are most relevant here. The parametric tests assume the data to be normally distributed and of equal-interval nature (that is someone who improved four points improved twice as much compared with someone who improved two points). In a nonparametric test, however, the assumption of being a normal distribution does not have to be met and, the data are assumed at an ordinal-metric level (i.e., that the original data can be validly ordered and that the difference between the two sets of data can be validly ordered). As stated by Lowry (1999) the choice is not simply a question of good manners or good taste. If there is one or more of these assumptions that cannot reasonably supposed to be satisfied, then the corresponding test for correlated samples cannot be legitimately applied. According to 
Motulsky (1995) a nonparametric test is definitively preferred in situations where either the population is clearly not normal or some values are 'off the scale', that is, too high or too low. To these, most experts add other situations in which nonparametric tests will be preferred: when testing in small samples $(<30)$ and when there are unequal variances across groups.

As it happens, it seems that most of these situations concur in the data presented here. On the one hand, the data presented is skewed. The Shapiro-Wilk normality test applied consecutively to data in Tables 1 through 4 rejects they are normally distributed. Neither they are the various subgroups of data in the tables or the differences between values and quantities in each table. The differences in volume for the trade originating in the United States and in Mexico are the only series at the edge of a normal distribution, but failed the test. With few data points, however, it is difficult to tell whether the data are Gaussian by inspection, and the formal test has little power to discriminate between normal and non-normal distributions. Nevertheless, nonparametric statistical test are to be used to assess variables that are skewed or which normality is doubted as in this case. On the other hand, it is clear that there are values off the scale, million dollars in the larger countries versus few thousands at the bottom end, which also applies to the quantities with million of tones versus few thousand kilograms. Besides, the equal-interval nature of the parametric tests it is difficult to assume here. A country with a 10,000 thousand dollars gap is not ten times as accurate as one with a gap of 100,000 thousand dollars, while the former may be a huge gap for Haiti, Bolivia or El Salvador, the latter may be a smallish gap for Chile, Uruguay or Argentina. In any event, when the data within two correlated samples fail to meet one or another of the assumptions of the parametric tests, the appropriate nonparametric alternative can be found in the Wilcoxon Matched-Pairs Signed-Ranks test (Wilcoxon-MPSR test, hereafter). 
The Wilcoxon-MPSR test, named after the work of the chemist and statistician Frank Wilcoxon (1945), is one of the cornerstones of nonparametric inferential statistics. ${ }^{3}$ This test is mostly applied in biological and medical sciences, although it has its foundations on an earlier paper by the economist Milton Friedman (1937). The assumptions of the Wilcoxon test, according to Lowry (1999) are: (a) that the paired values of $\mathrm{X}_{\mathrm{A}}$ and $\mathrm{X}_{\mathrm{B}}$ are randomly and independently drawn (i.e., each pair is drawn independently of all other pairs); (b) that the measured variable (e.g., a subject's probability estimate) is intrinsically continuous, capable in principle, if not in practice, of producing measures carried out to the ${ }^{\text {th }}$ decimal place; and (c) that the measures of $\mathrm{X}_{\mathrm{A}}$ and $\mathrm{X}_{\mathrm{B}}$ have the properties of at least an ordinal scale of measurement, so that it is meaningful to speak of "greater than," "less than," and "equal to."

The Wilcoxon-MPSR test can be used to determine whether the differences between the data registered by exporters and importers are meaningful, and if so, whether the differences are systematic in any direction. The Wilcoxon-MPSR tests the null hypothesis that there is no systematic difference within pairs against alternatives that assert a systematic difference (either one-sided or two-sided). Ignoring zero differences, the differences between the values in each pair are ranked without regard to sign. Then the sums of the positive ranks $\left(R^{+}\right)$and of the negative ranks $\left(R^{-}\right)$are calculated. For a two-tail test, the smaller of $R^{+}$and $R^{-}$is called $T$. This $T$ is the statistic that may be compared with the critical values in the appropriate statistical table (see Table 7). For one-tailed tests, $T$ will take the value of $R+$ or $R$-, depending of the specification of the alternative hypothesis. In plain language, if the null hypothesis was true and there was no difference between the two series compared, then we would expect the rank sums for positive and negative ranks to be the same, i.e. to have as many large positive as negative differences

\footnotetext{
${ }^{3}$ Do not confuse the Wilcoxon Matched-Pairs Signed-Ranks test with the other main test by the same author, the Wilcoxon Rank-Sum test, which compares one group with a hypothetical median.
} 
and as many small positive and negative differences. For the difference to be significant (i.e. to reject the null hypothesis) the calculated $T$ must be less than or equal to the tabulated value. Note that the Wilcoxon-MPSR $T$ statistic has a sampling distribution that is approximately normal when the number of pairs is large - say, $n \geq 15--$, close enough to allow for the calculation of a z-ratio, which can then be referred to the unit normal distribution, for the approximation formulae see Quang and Hong (2000).

Friedman (1937) when pondering nonparametric methods stated that 'it is evident that the method of ranks does not utilize all the information furnished by the data, since it relies solely on the order and makes no use of the quantitative magnitude of the variance. It is this very fact that makes it independent of the assumption of normality. At the same time, it is desirable to obtain some notion about the amount of information lost, that is about the efficiency of the method of ranks'. In the same paper, Friedman concluded that the loss of information in using the method of ranks is not very great. A positive aspect of the Wilcoxon-MPSR test is that it is a very powerful test. If all the assumptions for the parametric tests were met the Wilcoxon-MPSR has about 95 percent of the power of the parametric alternative. Further detail about the calculation and interpretation of the Wilcoxon-MPSR test can be found in Bland (1995) and Conover (1998).

\section{THE RESULTS}

Two different specifications of the Wilcoxon-MPSR test were designed for the data of Latin American imports of fossil fuels in 1925, one for the quantities and another one for the values. The test for quantities had no prior opinion regarding the direction of the mismatch: the data provided by the importers could either overvalue or undervalue the data registered at the ports of origin. Simply, this test goes along the line that the Latin American statistics are unusable and the errors could go in any direction. Thus in the first 
test the null hypothesis is $H_{0}$ : there is no systematic difference between importers' and exporters' tonnage data, versus an alternative $H_{1}$ : importers' tonnage records are different (greater or smaller) than exporters' data. The second test matched the usual assumptions explaining the discrepancies in values: data provided by the importers may be larger in value due to the difference between CIF and FOB registrations. Therefore in the second tests, applied to the value data, tests the null hypothesis $H_{0}$ : there is no systematic difference between importers' and exporters' value data, versus an alternative $H_{2}$ : importers' value records are larger than the values registered by the exporters.

Table 5 starts by reporting the STATA results when the Wilcoxon-MPSR test was applied to the total flows of trade measured in quantities (tonnage data in Tables 3 and 4). The column on the left summarizes the results for petroleum while the coal results appear on the column on the right hand side. The results of this first test for the quantities performed over the total flows are very clear: the null hypothesis cannot be rejected either for petroleum or for coal data at the levels of $p$ specified ( $p=0.05$ and $p=0.01$ ). That is the Wilcoxon-MPSR test found no compelling evidence that the tonnage data offered by exporters and importers differ when the flows of trade to each country are considered.

Furthermore, Table 5 also extended the test to the data in Tables 1 and 2. That is testing for individual exporters (for instance, exports of Mexico registered at Mexico contrasted with every country's record of Mexican oil imports). Such a test presumes that the discrepancies among the pairs are independent within exporters, and only tests for those cases where data is known at both ends and sufficient pairs are available $(\mathrm{N}>5)$. Again the results are very encouraging, for only in one case, the trade of petroleum from Germany to the Latin American countries, the null hypothesis can be rejected with confidence. Nevertheless, the trade of oil from Germany was insignificant for the region in absolute levels. Actually, it is due to its small magnitude that the data recorded at both 
ends differ: Germany did not report small trade while small countries did record this imports. In all other cases, for the tonnage of petroleum and coal imported, the null hypothesis cannot be rejected. Therefore, the Wilcoxon-MPSR test concludes that in the contrast of the Latin American imports of fossil fuels with each of the main trading partners, no systematic difference can be found in the tonnage data.

The expectation in the case of values was for rejecting the null hypothesis in most cases due to the assumptions of the literature: data provided by the importers may be larger in value due to the difference between CIF and FOB registrations. The results however point in a different direction. Table 6 present first the results of applying the Wilcoxon-MPSR test to the flows of trade in values given in Tables 3 and 4, and then extend the test to the pairs of values reported by each exporter (Tables 1 and 2). As in Table 5, the column on the left summarizes the results for petroleum while the coal results appear on the column on the right hand side.

The results for the contrast of the value of petroleum trade are striking. Again as in the case of quantities of petroleum traded, only the German data rejects the null hypothesis. For all the other data, including the total flows and the individual cross-checks for each exporter, the null hypothesis cannot be rejected. According to the WilcoxonMPSR test there is no systematic difference between importers' and exporters' reports of value traded in petroleum.

In the case of the value of coal traded, the null hypothesis is rejected in two relevant and related cases: in the aggregated flow of trade and in the trade from at the United Kingdom. The rejection on the null hypothesis, thus concluding that importers' value records are larger than the values registered by the exporters in the case of coal trade, seems more in accordance with the expectations of the literature. The issue then is why it is only found in these two cases and neither in the petroleum trade nor in the value of coal 
traded from the United States or Germany. The answer may lay on the different composition of the trade flows and the characteristics of the trade statistics of the destination countries. While almost two thirds of the coal trade had as destination countries applying CIF valuations and official prices, not even half of the oil trade had such countries as destination. In fact, most of the trade originating in the United States had as destination countries using FOB valuations in their imports and declared prices, which explains the test result of no systematic differences between the United States exports data and the Latin American importing records. On the contrary, over sixty per cent of the trade in coal that originated in the United Kingdom had as destination one single country Argentina, a country where imports were valued CIF and official prices were used. In addition, the omission by the British of the petty trade added to the overvaluation on the Latin American side.

In summary, the result of the Wilcoxon-MPSP test for the value of coal traded can be explained by the distinct composition of the coal trade flows and the characteristics of the trade statistics of the main destination countries. Nevertheless, these finding do not invalidate the fact that Argentina was the larger importer of coal of the region in 1925, whichever source used. It simply adds a caveat over the value given to such imports at the port of destination, especially if coming from the United Kingdom. As it does for the rest of the imports of coal, which according to these results, were overvalued with respect the value at origin.

The conclusion of the several exercises performed in this section is that only in very few cases we can accept the existence of statistically significant differences between the data provided by the exporters and the registered by the importing countries, and these only in value, never in volume. Given the nature of the products traded, the results are not so surprising. It should be pointed out that some works mention the fact that imports 
figures respond better to accuracy tests than export figures, for instance Federico and Tena (1991), Yeats (1995) and Kuntz (2002). Nevertheless, it should noticed that here the exports of petroleum of two Latin American countries, Mexico and Peru, have also passed the test. No significant difference can be found between the export reports of these two countries and the imports reported from them by the rest of the region, either in value or quantities.

\section{CONCLUSIONS}

The paper was aimed at proving that the story told from the exporter side is almost identical to the story told using the importers' figures when analyzing the Latin American countries within the context of the region. The question addressed, whether the differences observed are statistically (and economically) meaningful for the interpretation of the imports of petroleum and coal of the Latin American countries relative to each other found an answer making use of the Wilcoxon-MPSR test. The answer is that in quantities the differences are always unimportant statistically and economically. In values, the several exercises performed showed that only in very few cases we can accept the existence of statistically significant differences between the data provided by the exporters and the registered by the importing countries. The differences found are restricted to the values registered in coal trade, mostly trade from the United Kingdom, where the test rejected the null hypothesis thus concluding that the Latin American values were larger than the values registered at port of origin. It is worth remembering that 'how large is large' always depends on the question asked. Differences that at the country level may look abysmal, placed in the context of the region will be a minor problem for the analysis at hand.

This endorses the view that foreign trade statistics are more robust than previously thought for providing the basis of economic analysis. It is possible to extract some lessons 
from the Latin American trade data that withstand the mistrust on the original data sources. The results also point that the trade data of industrialized countries are compatible with the Latin American trade statistics and may serve as a reasonable supplement and complement to the regions' trade data. The historiography of Latin American describes its foreign trade statistics as mostly unusable. Our research and quantitative results contest this view.

Further research shall expand these results to other products in order to prove whether accuracy was restricted to homogeneous products. The examination shall also extend the time frame in order to explore whether the 1920s were an exceptionally good period for trade reporting. It would also be good to be able to test individual importers with respect to their trade partners (say Argentina's imports of petroleum versus all its suppliers rather than just the main ones) in order to study individual biases of trade. Researchers of using historical trade statistics may find useful some of the challenges to the literature that the scrutiny of the Latin American trade statistics brought into light: while it seems generally true that the exporters report values FOB, not all the importers reported their imports CIF in the 1920s, actually less than half of the 17 countries examined here, plus the United States. Finally, the wider field of economic measurement (in)accuracy may also benefit from the nonparametric test used here, since in most cases, economic data fit better the assumptions of nonparametric inferential statistics than the most widely used parametric ones. 


\section{REFERENCES}

\section{Official Publications}

Argentina: Dirección General de Estadística, Anuario del comercio exterior de la República Argentina (Buenos Aires, various years).

Belgium: Ministère des Finances, Tableau annuel du commerce avec les pays étrangers (Bruxelles, various years).

Bolivia: Dirección General de Aduanas, Comercio especial de Bolivia. Exportación-Importación (La Paz, various years).

Brazil: Directoria de Estatistica Commercial, Commercio exterior do Brasil (Rio de Janeiro, variours years).

Chile: Oficina Central de Estadística, Anuario Estadístico de la República de Chile: Comercio Exterior (Valparaíso, various years).

Colombia: Departamento de Contraloría, Anuario Estadístico. Comercio Exterior (Bogotá, various years).

Costa Rica: Dirección General de Estadística, Anuario Estadístico (San José, various years).

Cuba: Secretaría de Hacienda, Comercio Exterior (La Habana, various years).

Dominican Republic: Receptoría General de Aduanas, Report of the...fiscal period.Together with summary of commerce (Washington D.C., various years).

Ecuador: Dirección General de Estadística, Comercio Exterior del Ecuador en los años... (Quito, various years).

El Salvador: Dirección General de Estadística, Estadística comercial (San Salvador, various years).

Germany, Der Auswärtige Handel Deutschlands, (Berlin, various years).

Guatemala: Ministerio de Hacienda y Crédito Público, Memoria de las labores del Ejecutivo en el ramo de Hacienda y Crédito Público, . (Guatemala, various years).

México: Departamento de Estadística Nacional, Anuario Estadístico: Comercio exterior y navegación (México D.F., various years)

Nicaragua: Administración de Aduanas, Memoria del Recaudador General de Aduanas y las Estadísticas del Comercio de..., (Managua,, various years).

Paraguay: Dirección General de Estadística, El comercio exterior del Paraguay (Asunción, varoius years).

Perú: Superintendencia General de Aduanas, Estadística especial del Perú (Callao, various years).

U.S. Department of Commerce, The Foreign Commerce and Navigation of the United States (Washington D.C., various years).

United Kingdom: Statistical Office of the Customs and Excise Department, Annual Statement of the Trade of the United Kingdom with Foreign Countries and Britain possessions (London, various years).

Uruguay: Dirección General de Estadística, Anuario estadístico de la República Oriental del Uruguay (Montevideo, various years).

Venezuela: Ministerio de Hacienda y Crédito Público, Estadística mercantil y marítima (Caracas, various years).

\section{Secondary sources}

Allen, R. G. D., and E. J. Ely (1953): International Trade Statistics, New York: Wiley publications in statistics.

Bland, J. M. (1995): An Introduction to medical statistics. Oxford: Oxford University Press.

Carreras, A., A. Hofman, X. Tafunell, and C. Yañez (2003): El desarrollo económico de América Latina en épocas de globalización- Una agenda de investigación, Estudios Estadísticos y Prospectivos 24. Naciones Unidas. CEPAL. Centro de Proyecciones Económicas.

Carreras, A., C. Yañez, A. Hofman, X. Tafunell, M. Folchi D, and M. D. M. Rubio (2004): Importaciones y modernización económica en América Latina durante la primera mitad del siglo XX.Las claves de un programa de investigación, II Congreso Nacional de Historia Económica. Asociación Mexicana de Historia Económica, Mesa Temática No6.Universidad Autónoma de México.

Carreras-Marín, A., and M. Badía-Miró (2005, forthcoming): Geographical deviations in foreign trade statistics: a study into European trade with Latin American Countries 1925, UPF Economics Working Papers.

Conover, W. J. (1998): Practical nonparametric statistics. New York: Jon Wiley and sons. 
Don, Y. (1968): Comparability of International Trade Statistics. Great Britain and Austria-Hungary before World War I, Economic History Review XXXI.

Federico, G., and A. Tena (1991): On The Accuracy Of Foreign-Trade Statistics (1909-1935) - Morgenstern Revisited, Explorations in Economic History 28, 259-273.

Folchi, M., and M. D. M. Rubio (2004): El consumo aparente de energía fósil en los países latinoamericanos hacia 1925: una propuesta metodológica a partir de las estadísticas de comercio exterior, II Congreso Nacional de Historia Económica. Asociación Mexicana de Historia Económica Universidad Autóma de México.

Friedman, M. (1937): The Use of Ranks to Avoid the Assumption of Normality Implicit in the Analysis of Variance, Journal of the American Statistical Association 32, 675-701.

Kuntz, S. (2002): Nuevas series del comercio exterior de México, 1870-1929, Revista de Historia Económica XX:, 213270.

Lowry, R. (1999): Concepts and Applications of Inferential Statistics. Poughkeepsie, NY USA: Vassar College: http://faculty.vassar.edu/lowry/webtext.html.

Makhoul, B., and S. Otterstrom (1998): Exploring the accuracy of international trade statistics, Applied Economics 30, 1603-1616.

McGreevey, W. P. (1975): La investigación cuantitativa en la historia latinoamericana de los siglos XIX y XX, in Las Dimensiones del pasado: estudios de historia cuantitativa, ed. by Landes. et al. Madrid: Alianza, 325-354.

Moneta, C. (1959): The Estimation of Transportation Costs in International Trade, The Journal of Political Economy 67, 41-58.

Morgernstern, O. (1963): On the accuracy of economic observations. New Jersey: Princeton.

Motulsky, H. (1995): Choosing a statistical test, in Intuitive Biostatistics, ed. by H. Motulsky. Oxford: Oxford University Press.

Motulsky, H. (1995): Intuitive Biostatistics. Oxford: Oxford University Press.

Naya, S., and T. Morgan (1969): The accuracy of international trade data: the case of Sourth Asian contries, Journal of the American Statistical Association 64, 452-467.

Parniczky, G. (1980): On the inconsistency of world trade statistics, International Statistical Review 48, 43-48.

Platt, D. C. N. (1971): Problems in the Interpretation of Foreign Trade Statistics before 1914, Journal of Latin American Studies 3.

Quang, A. D., and B. T. Hong (2000): Statistical data analysis. Hanoi, Vietnam: UNESCO Training Course: http://www.netnam.vn/unescocourse.

Ricci, U. (1914): Sulle Divergenze fra Statistiche del Movimento Commerciale, Riforma Sociale 21, 337-412.

Rozansky, J., and A. Yeats (1994): On The (In)Accuracy Of Economic Observations - An Assessment Of Trends In The Reliability Of International-Trade Statistics, Journal of Development Economics 44, 103-130.

Rubio, M. D. M., and M. Folchi (may,2005): Energy as an indicator of modernisation in Latin America by 1925, UPF Economics Working Papers 868, 1-37.

Société Des Nations (1928): Mémorandum sur le Commerce International et sur les Balances de Paiements, 1912-1926. Genève: Publications de la Société des Nations.

U.S. Department of Commerce (1925,1926): Commerce Year Book. Washington: United States Government Printing Office.

U.S. Department of Commerce (by J.R.Bradley) (1931): Fuel and Power in Latin America. Washington: United States Government Printing Office.

Van Bergeijk, P. A. G. (1995): The Accuracy of International Economic Observations, Bulleting of Economic Research 47, 1-20.

Wilcoxon, F. (1945): Individual Comparisons by Ranking Methods, Biometrics Bulletin 1, 80-83.

Yeats, A. J. (1990): On the accuracy of economic observations: do sub-Saharan trade statistics mean anything, The World Bank Economic Review 4, 165-156.

Yeats, A. J. (1995): Are Partner-country Statistics Useful for Estimating "Missing Trade Data"?, World Bank Policy Research Working Paper 1501, 1-44. 
Table 1

Pairs of registered trade by exporters and importers:

Petroleum products imports of Latin America in 1925, by principal origin

\begin{tabular}{|c|c|c|c|c|c|c|c|}
\hline Country of origin & $\begin{array}{l}\text { Country of } \\
\text { destination }\end{array}$ & $\begin{array}{l}\text { Tones exported } \\
\text { (source: country } \\
\text { of origin) }\end{array}$ & $\begin{array}{l}\text { Tones imported } \\
\text { (source: country } \\
\text { of destination) }\end{array}$ & $\begin{array}{l}\text { U.S. dollars } \\
\text { exported } \\
\text { (source: country } \\
\text { of origin) }\end{array}$ & $\begin{array}{c}\text { U.S. dollars } \\
\text { imported } \\
\text { (source: country of } \\
\text { destination) }\end{array}$ & IMME tones & IMME value \\
\hline United States & Argentina & 338.920 & 271.606 & 14.023 .793 & 18.555 .730 & $-11 \%$ & $14 \%$ \\
\hline United States & Bolivia & 5.408 & 7.262 & 207.594 & 261.431 & $15 \%$ & $11 \%$ \\
\hline United States & Brasil & 243.176 & 210.200 & 15.907 .927 & 15.216 .036 & $-7 \%$ & $-2 \%$ \\
\hline United States & Colombia & 11.144 & 3.600 & 948.844 & 354.943 & $-51 \%$ & $-46 \%$ \\
\hline United States & Costa Rica & 11.774 & 1.597 & 308.165 & 224.728 & $-76 \%$ & $-16 \%$ \\
\hline United States & Cuba & 382.192 & 390.112 & 8.318 .516 & 7.137 .420 & $1 \%$ & $-8 \%$ \\
\hline United States & Chile & 766.852 & 700.859 & 8.655 .373 & 6.785 .093 & $-4 \%$ & $-12 \%$ \\
\hline United States & Ecuador & 16.660 & 1.459 & 337.918 & 210.713 & $-84 \%$ & $-23 \%$ \\
\hline United States & El Salvador & 9.841 & 19.902 & 297.011 & 385.263 & $34 \%$ & $13 \%$ \\
\hline United States & Guatemala & 2.173 & 31.005 & 212.244 & 377.887 & $87 \%$ & $28 \%$ \\
\hline United States & Haiti & 5.165 & 5.446 & 395.072 & 419.584 & $3 \%$ & $3 \%$ \\
\hline United States & Honduras & 63.042 & & 1.109 .116 & & & \\
\hline United States & Mexico & 324.314 & 361.357 & 6.233 .289 & 6.226 .786 & $5 \%$ & $-0,1 \%$ \\
\hline United States & Nicaragua & 9.140 & 7.246 & 582.948 & 299.470 & $-12 \%$ & $-32 \%$ \\
\hline United States & Panama & 612.898 & . & 6.815 .130 & . & & \\
\hline United States & Paraguay & 191 & & 19.217 & & & \\
\hline United States & Peru & 6.743 & 7.443 & 859.199 & 918.867 & $5 \%$ & $3 \%$ \\
\hline United States & R.Dominicana & 41.940 & 20.987 & 1.522 .542 & 943.512 & $-33 \%$ & $-23 \%$ \\
\hline United States & Uruguay & 112.157 & & 4.745 .413 & . & & \\
\hline United States & Venezuela & 14.021 & & 771.165 & & & \\
\hline Country of origin & $\begin{array}{l}\text { Country of } \\
\text { destination }\end{array}$ & $\begin{array}{l}\text { Tones exported } \\
\text { (source: country } \\
\text { of origin) }\end{array}$ & $\begin{array}{l}\text { Tones imported } \\
\text { (source: country } \\
\text { of destination) }\end{array}$ & $\begin{array}{l}\text { U.S. dollars } \\
\text { exported } \\
\text { (source: country } \\
\text { of origin) } \\
\end{array}$ & $\begin{array}{l}\text { U.S. dollars } \\
\text { imported } \\
\text { (source: country of } \\
\text { destination) } \\
\end{array}$ & IMME tones & IMME value \\
\hline Mexico & Argentina & 125.847 & 204.880 & 4.306 .868 & 13.367 .192 & $24 \%$ & $51 \%$ \\
\hline Mexico & Brasil & 308.234 & 295.359 & 3.582 .710 & 5.773 .082 & $-2 \%$ & $23 \%$ \\
\hline Mexico & Costa Rica & 23.698 & 37.155 & 218.143 & 255.629 & $22 \%$ & $8 \%$ \\
\hline Mexico & Cuba & 970.205 & 891.830 & 8.782 .727 & 5.960 .089 & $-4 \%$ & $-19 \%$ \\
\hline Mexico & Chile & 58.546 & 115.261 & 944.892 & 1.906 .791 & $33 \%$ & $34 \%$ \\
\hline Mexico & El Salvador & 190 & 18 & 8.010 & 1.058 & $-83 \%$ & $-77 \%$ \\
\hline Mexico & Guatemala & 47.090 & 34.355 & 610.993 & 957.097 & $-16 \%$ & $22 \%$ \\
\hline Mexico & Honduras & 44.570 & & 383.532 & & & \\
\hline Mexico & Nicaragua & 0 & 4.650 & 0 & 30.693 & $100 \%$ & $100 \%$ \\
\hline Mexico & Panama & 208.446 & & 1.694 .595 & & & \\
\hline Mexico & R.Dominicana & 4.969 & 9.797 & 46.850 & 91.902 & $33 \%$ & $32 \%$ \\
\hline Mexico & Uruguay & 71.526 & . & 601.599 & . & & \\
\hline Mexico & British Honduras & 863 & . & 29.327 & . & & \\
\hline Mexico & OtherBritishW.I.I. & 79.999 & . & 990.113 & 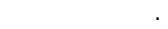 & & \\
\hline Mexico & Puerto Rico & 58.784 & & 502.281 & & & \\
\hline Country of origin & $\begin{array}{l}\text { Country of } \\
\text { destination }\end{array}$ & $\begin{array}{l}\text { Tones exported } \\
\text { (source: country } \\
\text { of origin) }\end{array}$ & $\begin{array}{l}\text { Tones imported } \\
\text { (source: country } \\
\text { of destination) }\end{array}$ & $\begin{array}{l}\text { U.S. dollars } \\
\text { exported } \\
\text { (source: country } \\
\text { of origin) }\end{array}$ & $\begin{array}{c}\text { U.S. dollars } \\
\text { imported } \\
\text { (source: country of } \\
\text { destination) }\end{array}$ & IMME tones & IMME value \\
\hline $\begin{array}{c}\text { Peru } \\
\end{array}$ & Argentina & 203.143 & 200.112 & 6.736 .498 & 19.556 .940 & $-1 \%$ & $49 \%$ \\
\hline Peru & Bolivia & 2.099 & 1.977 & 118.652 & 144.374 & $-3 \%$ & $10 \%$ \\
\hline Peru & Colombia & 693 & 456 & 29.981 & 33.872 & $-21 \%$ & $6 \%$ \\
\hline Peru & Costa Rica & 1.326 & 1.522 & 80.408 & 130.233 & $7 \%$ & $24 \%$ \\
\hline Peru & Chile & 97.312 & 90.392 & 2.696 .077 & 1.422 .106 & $-4 \%$ & $-31 \%$ \\
\hline Peru & Ecuador & 11.178 & 11.556 & 290.200 & 437.348 & $2 \%$ & $20 \%$ \\
\hline Peru & El Salvador & 2.041 & 2.616 & 129.657 & 173.978 & $12 \%$ & $15 \%$ \\
\hline Peru & Guatemala & 1.531 & 2.791 & 79.001 & 102.596 & $29 \%$ & $13 \%$ \\
\hline Peru & Nicaragua & 2.499 & 2.713 & U.S. dbAtars 612 & U.S. dott看605 & $4 \%$ & $13 \%$ \\
\hline $\begin{array}{l}\text { Peru } \\
\text { Coutnty of origin }\end{array}$ & $\frac{\text { Pesumitay of }}{\text { destination }}$ & 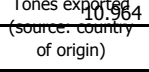 & 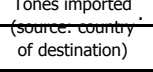 & $\begin{array}{c}\text { expotteg. } 136 \\
\text { (source: country } \\
\text { of origin) }\end{array}$ & $\begin{array}{c}\text { imported } \\
\begin{array}{c}\text { (source: country of } \\
\text { destination) }\end{array}\end{array}$ & IAAME tos & \\
\hline Germany & Argentina & 220 & 295 & 28.322 & 36.249 & $14 \%$ & $12 \%$ \\
\hline Germany & Bolivia & 0 & 4 & 0 & 499 & $100 \%$ & $100 \%$ \\
\hline Germany & Brasil & 92 & 94 & 11.186 & 22.294 & $1 \%$ & $33 \%$ \\
\hline Germany & Colombia & 0 & 28 & 0 & 4.442 & $100 \%$ & $100 \%$ \\
\hline Germany & Costa Rica & 0 & 15 & 0 & 2.273 & $100 \%$ & $100 \%$ \\
\hline Germany & Chile & 33 & 10 & 2.856 & 1.573 & $-52 \%$ & $-29 \%$ \\
\hline Germany & Ecuador & 0 & 55 & 0 & 8.057 & $100 \%$ & $100 \%$ \\
\hline Germany & El Salvador & 0 & 7 & 0 & 623 & $100 \%$ & $100 \%$ \\
\hline Germany & Guatemala & 0 & 17 & 0 & 2.484 & $100 \%$ & $100 \%$ \\
\hline Germany & Haiti & 0 & 1 & 0 & 133 & $100 \%$ & $100 \%$ \\
\hline Germany & Mexico & 16 & 81 & 3.808 & 12.482 & $67 \%$ & $53 \%$ \\
\hline Germany & Nicaragua & 0 & 7 & 0 & 1.057 & $100 \%$ & $100 \%$ \\
\hline Germany & Peru & 0 & 99 & 0 & 12.582 & $100 \%$ & $100 \%$ \\
\hline Germany & R.Dominicana & 0 & 0,2 & 0 & 49 & $100 \%$ & $100 \%$ \\
\hline Country of origin & $\begin{array}{l}\text { Country of } \\
\text { destination }\end{array}$ & $\begin{array}{l}\text { Tones exported } \\
\text { (source: country } \\
\text { of origin) }\end{array}$ & $\begin{array}{l}\text { Tones imported } \\
\text { (source: country } \\
\text { of destination) }\end{array}$ & $\begin{array}{l}\text { U.S. dollars } \\
\text { exported } \\
\text { (source: country } \\
\text { of origin) }\end{array}$ & $\begin{array}{l}\text { U.S. dollars } \\
\text { imported } \\
\text { (source: country of } \\
\text { destination) }\end{array}$ & IMME tones & IMME value \\
\hline United Kingdom & Argentina & 1.916 & 295 & 292.686 & 52.956 & $-73 \%$ & $-69 \%$ \\
\hline United Kingdom & Bolivia & 0 & 525 & 0 & 74.867 & $100 \%$ & $100 \%$ \\
\hline United Kingdom & Brasil & 644 & 100 & 90.003 & 8.027 & $-73 \%$ & $-84 \%$ \\
\hline United Kingdom & Colombia & 0 & 104 & 0 & 14.888 & $100 \%$ & $100 \%$ \\
\hline United Kingdom & Costa Rica & 0 & 8 & 0 & 1.304 & $100 \%$ & $100 \%$ \\
\hline United Kingdom & Cuba & 0 & 8 & 0 & 514 & $100 \%$ & $100 \%$ \\
\hline United Kingdom & Chile & 369 & 17 & 60.623 & 1.720 & $-91 \%$ & $-94 \%$ \\
\hline United Kingdom & Ecuador & 0 & 30 & 0 & 4.957 & $100 \%$ & $100 \%$ \\
\hline United Kingdom & El Salvador & 0 & 6 & 0 & 1.942 & $100 \%$ & $100 \%$ \\
\hline United Kingdom & Guatemala & 0 & 79 & 0 & 9.334 & $100 \%$ & $100 \%$ \\
\hline United Kingdom & Haiti & 0 & 0,4 & 0 & 110 & $100 \%$ & $100 \%$ \\
\hline United Kingdom & Mexico & 0 & 10 & 0 & 2.474 & $100 \%$ & $100 \%$ \\
\hline United Kingdom & Nicaragua & 0 & 21 & 0 & 3.613 & $100 \%$ & $100 \%$ \\
\hline United Kingdom & Peru & 0 & 459 & 0 & 64.975 & $100 \%$ & $100 \%$ \\
\hline United Kingdom & R.Dominicana & 0 & 0,4 & 0 & 86 & $100 \%$ & $100 \%$ \\
\hline
\end{tabular}

Notes: a cero indicates no trade reported in the source of reference, a dot indicates source not available

$\mathrm{IMME}=\{($ destination source - origin source $) /($ destination source + origin source $) * 100\}$. 
Table 2

Pairs of registered trade by exporters and importers:

Coal imports of Latin America in 1925, by principal origin

\begin{tabular}{|c|c|c|c|c|c|c|c|}
\hline Country of origin & $\begin{array}{l}\text { Country of } \\
\text { destination }\end{array}$ & $\begin{array}{l}\text { Tones exported } \\
\text { (source: country of } \\
\text { origin) }\end{array}$ & $\begin{array}{l}\text { Tones imported } \\
\text { (source: country } \\
\text { of destination) }\end{array}$ & $\begin{array}{c}\text { U.S. dollars } \\
\text { exported } \\
\text { (source: country } \\
\text { of oriain) }\end{array}$ & $\begin{array}{c}\text { U.S. dollars } \\
\text { imported } \\
\text { (source: country } \\
\text { of destination) }\end{array}$ & IMME tones & IMME value \\
\hline United Kingdom & Argentina & 2.444 .917 & 2.768 .735 & 15.685 .196 & 29.954 .051 & $6 \%$ & $31 \%$ \\
\hline United Kingdom & Bolivia & 564 & 4.614 & 6.688 & 53.359 & $78 \%$ & $78 \%$ \\
\hline United Kingdom & Brasil & 1.195 .484 & 1.081 .395 & 7.367.011 & 9.732 .788 & $-5 \%$ & $14 \%$ \\
\hline United Kingdom & Colombia & 1.429 & 1.609 & 9.484 & 11.789 & $6 \%$ & $11 \%$ \\
\hline United Kingdom & Costa Rica & 0 & 312 & 0 & 3.384 & $100 \%$ & $100 \%$ \\
\hline United Kingdom & Cuba & 6.814 & 7.366 & 59.836 & 52.481 & $4 \%$ & $-7 \%$ \\
\hline United Kingdom & Chile & 143.736 & 208.829 & 768.719 & 967.597 & $18 \%$ & $11 \%$ \\
\hline United Kingdom & Ecuador & 0 & 77 & 0 & 878 & $100 \%$ & $100 \%$ \\
\hline United Kingdom & Mexico & 0 & 380 & 0 & 9.324 & $100 \%$ & $100 \%$ \\
\hline United Kingdom & Nicaragua & 0 & 357 & 0 & 382 & $100 \%$ & $100 \%$ \\
\hline United Kingdom & Peru & 10.220 & 17.660 & 69.552 & 158.416 & $27 \%$ & $39 \%$ \\
\hline United Kingdom & Uruguay & 343.207 & . & 2.049 .007 & . & & \\
\hline United Kingdom & Venezuela & 19.355 & & 130.624 & . & & \\
\hline Country of origin & $\begin{array}{l}\text { Country of } \\
\text { destination }\end{array}$ & $\begin{array}{l}\text { Tones exported } \\
\text { (source: country of } \\
\text { origin) }\end{array}$ & $\begin{array}{l}\text { Tones imported } \\
\text { (source: country } \\
\text { of destination) }\end{array}$ & $\begin{array}{l}\text { U.S. dollars } \\
\text { exported } \\
\text { (source: country } \\
\text { of origin) }\end{array}$ & $\begin{array}{l}\text { U.S. dollars } \\
\text { imported } \\
\text { (source: country } \\
\text { of destination) }\end{array}$ & IMME tones & IMME value \\
\hline United States & Argentina & 149.417 & 150.569 & 669.079 & 1.626 .988 & $0 \%$ & $42 \%$ \\
\hline United States & Bolivia & 0 & 1.017 & 0 & 8.932 & $100 \%$ & $100 \%$ \\
\hline United States & Brasil & 596.798 & 631.318 & 2.714 .739 & 5.402 .663 & $3 \%$ & $33 \%$ \\
\hline United States & Colombia & 1.696 & 1.643 & 12.458 & 16.180 & $-2 \%$ & $13 \%$ \\
\hline United States & Costa Rica & 78 & 496 & 1.610 & 4.252 & $73 \%$ & $45 \%$ \\
\hline United States & Cuba & 694.893 & 652.023 & 3.453 .898 & 3.062 .379 & $-3 \%$ & $-6 \%$ \\
\hline United States & Chile & 40.546 & 38.210 & 225.035 & 200.908 & $-3 \%$ & $-6 \%$ \\
\hline United States & Ecuador & 1.116 & 1.095 & 7.131 & 7.392 & $-1 \%$ & $2 \%$ \\
\hline United States & El Salvador & 113 & 154 & 1.952 & 7.068 & $15 \%$ & $57 \%$ \\
\hline United States & Guatemala & 3.287 & 264 & 18.524 & 3.279 & $-85 \%$ & $-70 \%$ \\
\hline United States & Haiti & 83 & 156 & 1.275 & 2.771 & $30 \%$ & $37 \%$ \\
\hline United States & Honduras & 1.943 & . & 1.368 & . & & \\
\hline United States & Mexico & 118.393 & 65.324 & 505.847 & 555.681 & $-29 \%$ & $5 \%$ \\
\hline United States & Nicaragua & 2.476 & 2.289 & 11.238 & 11.538 & $-4 \%$ & $1 \%$ \\
\hline United States & Panama & 317.994 & . & 1.559 .705 & . & & \\
\hline United States & Paraguay & 24 & . & 432 & . & & \\
\hline United States & Peru & 19.473 & 17.813 & 111.891 & 105.665 & $-4 \%$ & $-3 \%$ \\
\hline United States & R.Dominicana & 9.484 & 9.697 & 69.440 & 77.157 & $1 \%$ & $5 \%$ \\
\hline United States & Uruguay & 20.133 & . & 92.240 & . & & \\
\hline United States & Venezuela & 839 & . & 6.042 & & & \\
\hline Country of origin & $\begin{array}{l}\text { Country of } \\
\text { destination }\end{array}$ & $\begin{array}{l}\text { Tones exported } \\
\text { (source: country of } \\
\text { origin) }\end{array}$ & $\begin{array}{l}\text { Tones imported } \\
\text { (source: country } \\
\text { of destination) }\end{array}$ & $\begin{array}{l}\text { U.S. dollars } \\
\text { exported } \\
\text { (source: country } \\
\text { of origin) }\end{array}$ & $\begin{array}{l}\text { U.S. dollars } \\
\text { imported } \\
\text { (source: country } \\
\text { of destination) }\end{array}$ & IMME tones & IMME value \\
\hline Germany & Argentina & 324.750 & 192.450 & 1.606 .976 & 2.082 .097 & $-26 \%$ & $13 \%$ \\
\hline Germany & Bolivia & 100 & 446 & 714 & 455 & $63 \%$ & $-22 \%$ \\
\hline Germany & Brasil & 19.654 & 474 & 104.482 & 10.540 & $-95 \%$ & $-82 \%$ \\
\hline Germany & Chile & 10.515 & 5.995 & 61.642 & 53.249 & $-27 \%$ & $-7 \%$ \\
\hline Germany & Ecuador & 15 & 15 & 238 & 192 & $1 \%$ & $-11 \%$ \\
\hline Germany & El Salvador & 0 & 0,02 & 0 & 3 & $100 \%$ & $100 \%$ \\
\hline Germany & Mexico & 250 & 43 & 1.190 & 1.788 & $-71 \%$ & $20 \%$ \\
\hline Germany & Peru & 2.850 & 2.916 & 15.946 & 17.752 & $1 \%$ & $5 \%$ \\
\hline Germany & Uruguay & 22.116 & . & 105.910 & $\cdot$ & & \\
\hline Germany & Venezuela & 643 & & 2.856 & 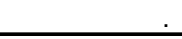 & & \\
\hline Country of origin & $\begin{array}{l}\text { Country of } \\
\text { destination }\end{array}$ & $\begin{array}{l}\text { Tones exported } \\
\text { (source: country of } \\
\text { origin) }\end{array}$ & $\begin{array}{l}\text { Tones imported } \\
\text { (source: country } \\
\text { of destination) }\end{array}$ & $\begin{array}{l}\text { U.S. dollars } \\
\text { exported } \\
\text { (source: country } \\
\text { of origin) }\end{array}$ & $\begin{array}{l}\text { U.S. dollars } \\
\text { imported } \\
\text { (source: country } \\
\text { of destination) }\end{array}$ & IMME tones & IMME value \\
\hline Belgium & Argentina & 6.008 & 225 & 54.625 & 2.431 & $-93 \%$ & $-91 \%$ \\
\hline Belgium & Brasil & 2.200 & 2.016 & 12.540 & 13.408 & $-4 \%$ & $3 \%$ \\
\hline Belgium & Chile & 400 & 520 & 2.090 & 5.295 & $13 \%$ & $43 \%$ \\
\hline
\end{tabular}

Sources: Official publications listed in the references

Notes: a cero indicates no trade reported in the source of reference, a dot indicates source not available

$\mathrm{IMME}=\{($ destination source - origin source)/(destination source + origin source)*100 $\}$. 
Table 3

Petroleum products imports of Latin America in 1925, totals from principal partners

\begin{tabular}{|c|c|c|c|c|c|c|c|}
\hline Country of origin & $\begin{array}{l}\text { Country of } \\
\text { destination }\end{array}$ & $\begin{array}{l}\text { Tones exported } \\
\text { (source: } \\
\text { countries of } \\
\text { origin) }\end{array}$ & $\begin{array}{l}\text { Tones imported } \\
\text { (source: country } \\
\text { of destination) }\end{array}$ & $\begin{array}{l}\text { U.S. dollars } \\
\text { exported } \\
\text { (source: countries } \\
\text { of origin) }\end{array}$ & $\begin{array}{l}\text { U.S. dollars imported } \\
\text { (source: country of } \\
\text { destination) }\end{array}$ & IMME tones & IMME value \\
\hline G3+Mexico+Peru & Argentina & 670.046 & 677.187 & 25.388 .166 & 51.569 .067 & $0,5 \%$ & $34 \%$ \\
\hline G3+Mexico+Peru & Bolivia & 7.506 & 9.768 & 326.246 & 481.170 & $13,1 \%$ & $19 \%$ \\
\hline G3+Mexico+Peru & Brasil & 552.147 & 505.753 & 19.591 .826 & 21.019 .438 & $-4,4 \%$ & $4 \%$ \\
\hline G3+Mexico+Peru & Colombia & 11.838 & 4.189 & 978.825 & 408.144 & $-47,7 \%$ & $-41 \%$ \\
\hline G3+Mexico+Peru & Costa Rica & 36.799 & 40.298 & 606.716 & 614.167 & $4,5 \%$ & $1 \%$ \\
\hline G3+Mexico+Peru & Cuba & 1.352 .397 & 1.281 .949 & 17.101 .243 & 13.098 .023 & $-2,7 \%$ & $-13 \%$ \\
\hline G3+Mexico+Peru & Chile & 923.112 & 906.540 & 12.359 .821 & 10.117.282 & $-0,9 \%$ & $-10 \%$ \\
\hline G3+Mexico+Peru & Ecuador & 27.838 & 13.100 & 628.118 & 661.074 & $-36,0 \%$ & $3 \%$ \\
\hline G3+Mexico+Peru & El Salvador & 12.072 & 22.549 & 434.678 & 562.864 & $30,3 \%$ & $13 \%$ \\
\hline G3+Mexico+Peru & Guatemala & 50.794 & 68.247 & 902.237 & 1.449 .398 & $14,7 \%$ & $23 \%$ \\
\hline G3+Mexico+Peru & Haiti & 5.165 & 5.446 & 395.072 & 419.694 & $2,6 \%$ & $3 \%$ \\
\hline G3+Mexico+Peru & Mexico & 324.330 & 361.448 & 6.237 .097 & 6.241 .741 & $5,4 \%$ & $0 \%$ \\
\hline G3+Mexico+Peru & Nicaragua & 11.639 & 14.615 & 705.560 & 491.826 & $11,3 \%$ & $-18 \%$ \\
\hline G3+Mexico+Peru & Peru & 6.743 & 8.006 & 859.199 & 996.424 & $8,6 \%$ & $7 \%$ \\
\hline G3+Mexico+Peru & R.Dominicana & 46.908 & 30.784 & 1.569 .392 & 1.035 .500 & $-20,8 \%$ & $-20 \%$ \\
\hline G3+Mexico+Peru & Uruguay & 183.684 & 226.045 & 5.347 .012 & 7.381 .505 & $10,3 \%$ & $16 \%$ \\
\hline G3+Mexico+Peru & Venezuela & 14.021 & 8.552 & 771.165 & 798.032 & $-24,2 \%$ & $2 \%$ \\
\hline
\end{tabular}

Sources and notes: Table 1, exept for the total quantities and values imported by Uruguay and Venezuela, which correspond to the total imports reported in their respective trade statistics

G3 refers to United States, United Kingdom and Germany

$\mathrm{IMME}=\{$ (destination source - origin source)/(destination source + origin source)*100 $\}$.

Table 4

Coal imports of Latin America in 1925, totals from principal partners

\begin{tabular}{|c|c|c|c|c|c|c|c|}
\hline Country of origin & $\begin{array}{l}\text { Country of } \\
\text { destination }\end{array}$ & $\begin{array}{l}\text { Tones exported } \\
\text { (source: } \\
\text { countries of } \\
\text { origin) }\end{array}$ & $\begin{array}{l}\text { Tones imported } \\
\text { (source: country } \\
\text { of destination) }\end{array}$ & $\begin{array}{l}\text { U.S. dollars } \\
\text { exported } \\
\text { (source: countries } \\
\text { of origin) }\end{array}$ & $\begin{array}{l}\text { U.S. dollars imported } \\
\text { (source: country of } \\
\text { destination) }\end{array}$ & IMME tones & IMME value \\
\hline Total G4 & Argentina & 2.925 .091 & 3.111 .979 & 18.015 .876 & 33.665 .568 & $3 \%$ & $30 \%$ \\
\hline Total G4 & Bolivia & 664 & 6.077 & 7.402 & 62.747 & $80 \%$ & $79 \%$ \\
\hline Total G4 & Brasil & 1.814 .136 & 1.715 .203 & 10.198 .772 & 15.159.399 & $-3 \%$ & $20 \%$ \\
\hline Total G4 & Colombia & 3.125 & 3.252 & 21.942 & 27.970 & $2 \%$ & $12 \%$ \\
\hline Total G4 & Costa Rica & 78 & 808 & 1.610 & 7.636 & $82 \%$ & $65 \%$ \\
\hline Total G4 & Cuba & 701.707 & 659.389 & 3.513 .734 & 3.114 .860 & $-3 \%$ & $-6 \%$ \\
\hline Total G4 & Chile & 195.197 & 253.554 & 1.057 .486 & 1.227 .050 & $13 \%$ & $7 \%$ \\
\hline Total G4 & Ecuador & 1.131 & 1.187 & 7.369 & 8.462 & $2 \%$ & $7 \%$ \\
\hline Total G4 & El Salvador & 113 & 154 & 1.952 & 7.071 & $15 \%$ & $57 \%$ \\
\hline Total G4 & Guatemala & 3.287 & 264 & 18.524 & 3.279 & $-85 \%$ & $-70 \%$ \\
\hline Total G4 & Haiti & 83 & 156 & 1.275 & 2.771 & $30 \%$ & $37 \%$ \\
\hline Total G4 & Mexico & 118.643 & 65.746 & 507.037 & 566.793 & $-29 \%$ & $6 \%$ \\
\hline Total G4 & Nicaragua & 2.476 & 2.646 & 11.238 & 11.920 & $3 \%$ & $3 \%$ \\
\hline Total G4 & Peru & 32.542 & 38.389 & 197.389 & 281.834 & $8 \%$ & $18 \%$ \\
\hline Total G4 & R.Dominicana & 9.484 & 9.697 & 69.440 & 77.157 & $1 \%$ & $5 \%$ \\
\hline Total G4 & Uruguay & 385.457 & 352.531 & 2.245 .157 & 3.468 .769 & $-4 \%$ & $21 \%$ \\
\hline \multirow[t]{2}{*}{ Total G4 } & Venezuela & 20.837 & 23.816 & 139.522 & 156.887 & $7 \%$ & $6 \%$ \\
\hline & otal 17 count & 6.214 .051 & 6.244 .847 & 36.015 .726 & 57.850 .172 & $0,2 \%$ & $23 \%$ \\
\hline
\end{tabular}

Sources and notes: Table 1, exept for the total quantities and values imported by Uruguay and Venezuela, which

correspond to the total imports reported in their respective trade statistics.

G4 refers to United States, United Kingdom, Germany and Belgium

$\mathrm{IMME}=\{($ destination source - origin source $) /($ destination source + origin source $) * 100\}$. 


\section{Table 5 A nonparametric test for quantities imported by Latin America}

$\mathrm{H}_{0}$ : there is no systematic difference between importers and exporters tonnage data

$\mathrm{H}_{1}$ : importers' tonnage records are different (greater or smaller) than exporters' data

Two-tail test:

Test statistic: $\mathrm{T}=\min (\mathrm{R}-, \mathrm{R}+$ ) (in bold in the results below)

Rejection region: $\mathrm{T} \leq \mathrm{T}_{\text {crit }}$ for small samples // for large samples $z\left\langle-z_{a / 2}\right.$ or $\left.z\right\rangle z_{a} / a$

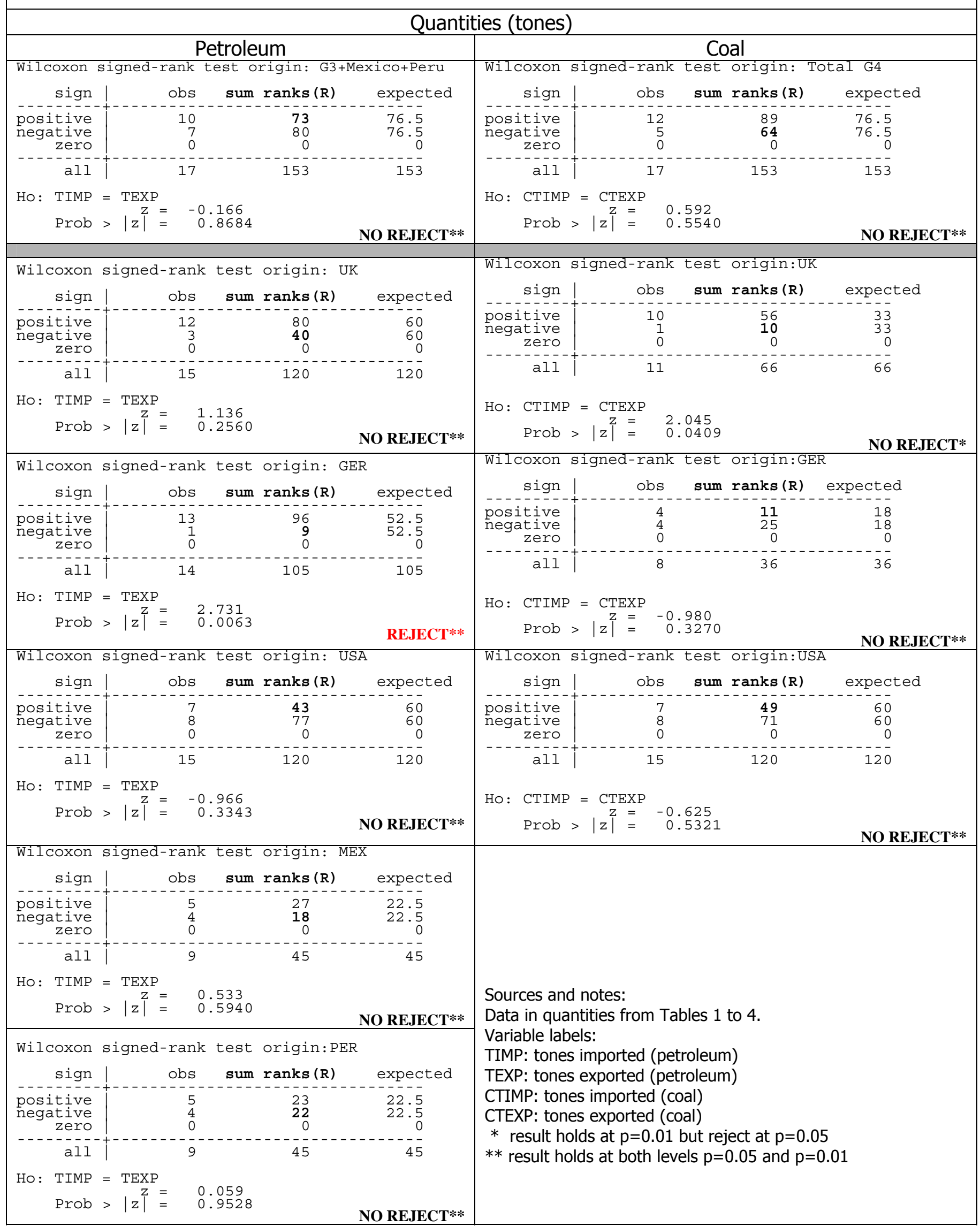


Table 6 A nonparametric test for values imported by Latin America

$\mathrm{H}_{0}$ : there is no systematic difference between importers and exporters tonnage data

$\mathrm{H}_{2}$ : importers' value records are larger than the values registered by exporters

Two-tail test:

Test statistic: $\mathrm{T}=\mathrm{R}$ - (in bold in the results below)

Rejection region: $\mathrm{T} \leq \mathrm{T}_{\text {crit }}$ for small samples $/ /$ for large samples $z>z_{x}$ (or $z<-z_{x}$ )

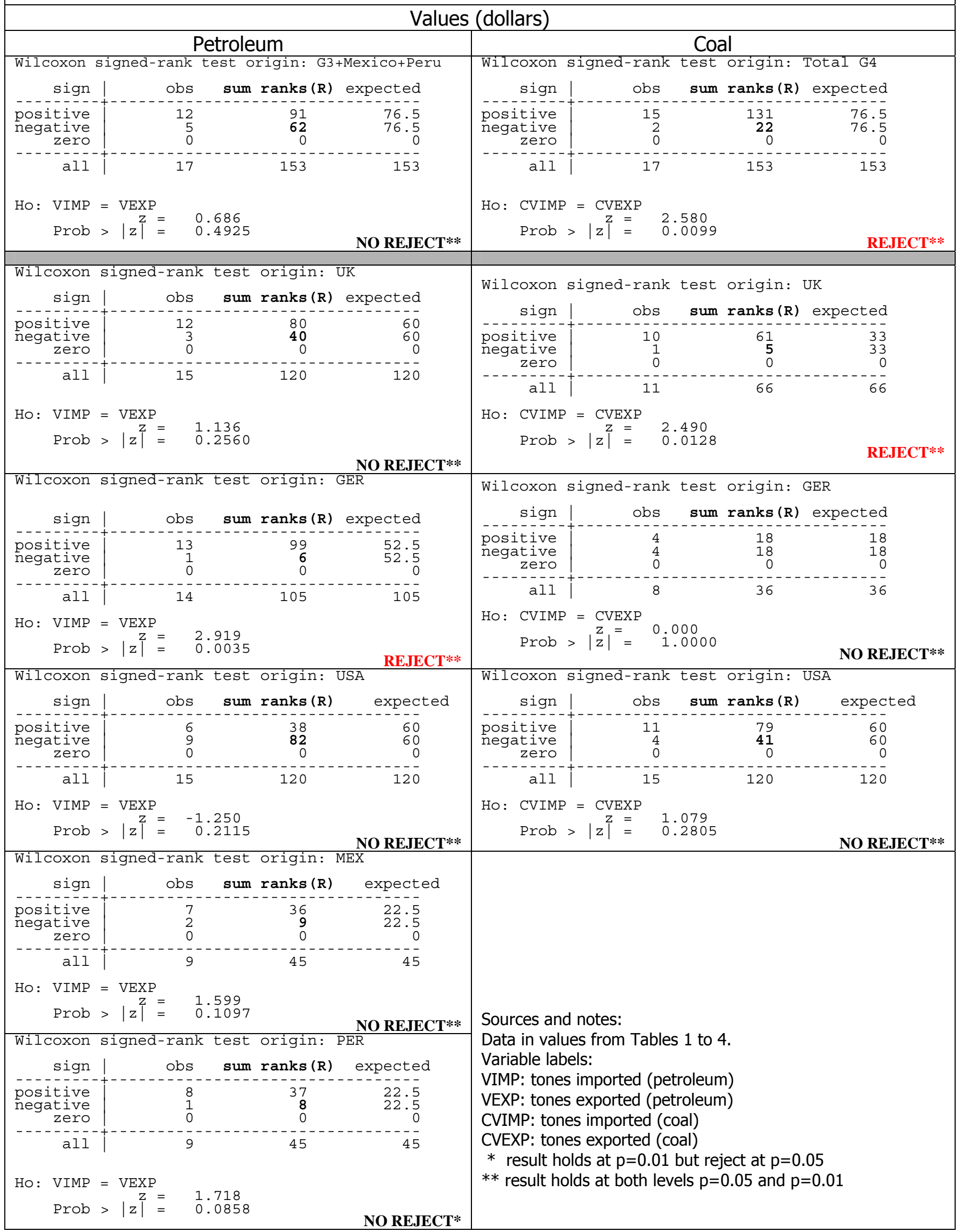




\section{Table 7: Critical values of the Wilcoxon Matched Pairs Signed Rank Test}

For any $\mathrm{N}$ (number of subject minus ties) the observed value is significant at a given level of significance if it is equal to or less than the critical value shown in table below.

\begin{tabular}{rrrrrr}
\hline & One-tailed Test & & \multicolumn{2}{c}{ Two-tailed Test } \\
\cline { 1 - 2 } \cline { 5 - 6 }$N$ & $\mathrm{p} \leq 0.05$ & $\mathrm{p} \leq 0.01$ & & $\mathrm{p} \leq 0.05$ & $\mathrm{p} \leq 0.01$ \\
\hline 5 & 1 & - & & - & - \\
6 & 2 & - & & 1 & - \\
7 & 4 & 0 & & 2 & - \\
8 & 6 & 2 & & 4 & 0 \\
9 & 8 & 3 & & 6 & 2 \\
10 & 11 & 5 & & 8 & 3 \\
11 & 14 & 7 & & 11 & 5 \\
12 & 17 & 10 & & 14 & 7 \\
13 & 21 & 13 & & 17 & 10 \\
14 & 26 & 16 & & 21 & 13 \\
15 & 30 & 20 & & 25 & 16 \\
16 & 36 & 24 & & 30 & 19 \\
17 & 41 & 28 & & 35 & 23 \\
18 & 47 & 33 & & 40 & 28 \\
19 & 54 & 38 & & 46 & 32 \\
20 & 60 & 43 & & 52 & 37 \\
\hline
\end{tabular}

Source: Statistical Tables, School of Psychology, University of Nottingham, University Park, Nottingham, NG7 2RD, UK, available at:

http://www.psychology.nottingham.ac.uk/courses/modules/statsguides/StatisticalTables.htm.

The first column also serves for the critical values of the two-tailed test at $p \leq 0.10$ 


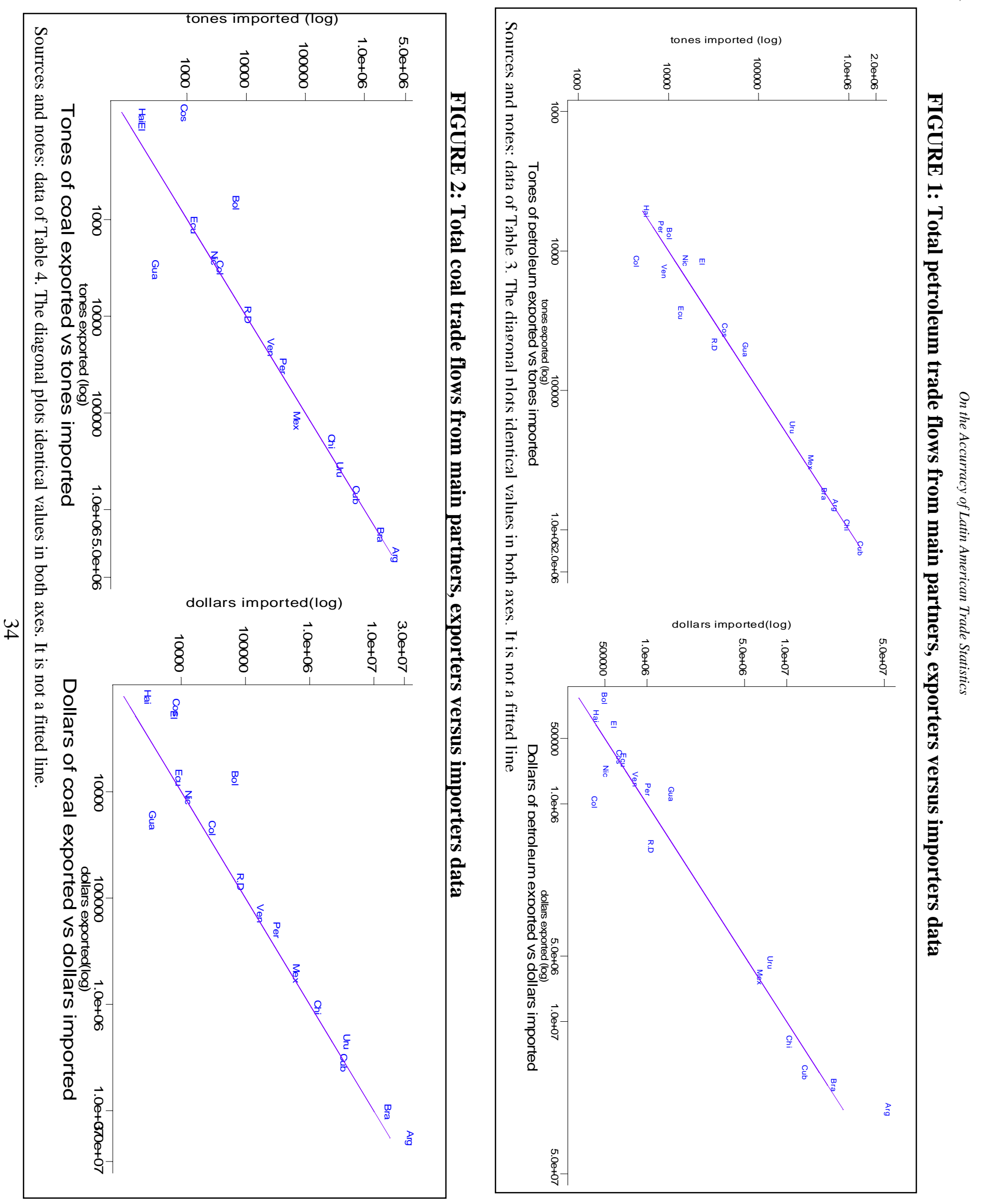

